\title{
Investigation of the Effects of First and Second Trimester Biochemical Markers and Ultrasonographic Measurements on Infant Birth Weight
}

\author{
Yeliz Çeçen Dönmez, Önder Sakin, Zehra Meltem Pirimoğlu, \\ Ömer Talip Turhan, Gülçin Şahin Ersoy, Seda Subaşı
}

Department of Obstetrics and Gynecology Clinic, Kartal Dr. Lütfi Kırdar Training and Research Hospital, İstanbul, Turkey

Submitted: 13.01.2015 Accepted: 13.04.2015

Correspondence: Önder Sakin Kartal Dr. Lütfi Kırdar Eğit. ve Araş. Hast., Kadın Hastalıkları ve Doğum

Kliniği, Cevizli, İstanbul, Turkey E-mail: sakin-onder@hotmail.com

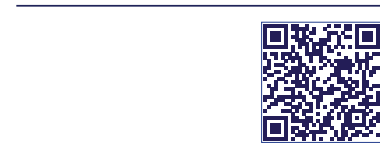

Keywords: Doppler ultrasonography; HCGbeta; nuchal translucency measurement; PAPP-A; small for gestational age.

\begin{abstract}
Objective: This study investigated the relationship between pregnancy-associated plasma protein-A (PAPP-A), free beta-human chorionic gonadotropin ( $\beta \mathrm{hCG}$ ), alpha-fetoprotein (AFP), nuchal translucency (NT), crown-rump length (CRL), and second trimester Doppler ultrasound (US) indices of uterine arteries and birth weight, and evaluated predictive value of the data for intrauterine growth retardation (IUGR).
\end{abstract}

Methods: A total of 103 patients in first trimester who came to the hospital obstetric clinic for routine prenatal examination between June 2010 and June $201 \mathrm{I}$ were included in the study. Patients were divided into 2 groups: IUGR group with birth weight below $10^{\text {th }}$ percentile and the control group. In all, 83 infants were of normal birth weight and 20 were small for gestational age (SGA).

Results: Mean body mass index (BMI) of women who delivered SGA babies was significantly lower than that of the control group $(p=0.03)$. There were no statistically significant differences between groups in terms of PAPP-A levels, $\beta$ hCG levels, CRL, NT measurements, or hemoglobin levels. There was no difference in fetal biophysical measurements. Although diastolic notch in uterine arteries was seen more frequently in SGA group, it did not reach the level of significance. Second trimester maternal serum AFP levels evaluated as multiple of median (MoM) were higher in SGA group than in the control group $(p=0.009)$. Findings were confirmed with Pearson correlation analysis $(p=0.028 ; r=-0.327)$.

Conclusion: First trimester maternal serum screening markers were not associated with SGA fetus. Presence of diastolic notch in bilateral uterine arteries at 20 and 24 weeks may have a value for predicting SGA fetus. Higher MoM levels of maternal serum AFP were associated with SGA fetus.

\section{INTRODUCTION}

Many terminologies have been used to define babies who are small for gestational age. These include small for gestational age (SGA), intrauterine growth retardation IUGR) and fetal growth restriction. Most of the time, SGA is used for newborn, and IUGR for fetus. Babies weighing less than $10^{\text {th }}$ percentile of their age-adjusted birth weight are considered SGA.[ ${ }^{[]}$

Early detection of SGA risk in fetus will help investigators evaluate healthcare expenditures of pregnancy and decide on most suitable time for delivery. In addition, early diagnosis of IUGR can provide up to four times better prognosis for SGA 
babies. ${ }^{[2]}$

Unfortunately, despite modern obstetric methods, IUGR is still a determinative factor in perinatal mortality and morbidity. ${ }^{[3]}$

Fetuses with extreme preterm IUGR represent the high risk group for neonatal mortality and morbidity. ${ }^{[4,5]}$ When long-term outcomes are taken into consideration, researchers have reported a wide spectrum of outcomes, ranging from minor decrease in IQ to serious increase in risk for cerebral palsy. ${ }^{[6,7]}$ Careful monitoring of fetal growth and optimal determination of type and timing of delivery provide the best possible result. Lubchenco et al. detected a dramatic increase in mortality and morbidity if birth weight of newborn delivered at any gestational age is lower than the $10^{\text {th }}$ percentile of gestational age-adjusted normal birth weight. ${ }^{[8]}$ Perinatal mortality and morbidity increase significantly when birth weight decreases from the $10^{\text {th }}$ percentile. ${ }^{[9]}$

Generally, infants born with body weight varying from 1500 to 2500 grams between $38^{\text {th }}$ and $42^{\text {nd }}$ gestational weeks have 5 to 30 times higher perinatal morbidity and mortality rates than those with body weight between $10^{\text {th }}$ and $90^{\text {th }}$ percentiles. Incidence of perinatal morbidity and mortality increases multifold in newborns weighing less than 1500 grams. $^{[10]}$

In the normal population, median value of pregnancy-associated plasma protein-A (PAPP-A) is 1.0 multiples of median (MoM). ${ }^{[1,12]}$ There is a direct proportion between serum PAPP-A level, weight of placenta, and birth weight, while an inverse proportion exists between serum PAPP-A level and body weight of the pregnant woman. ${ }^{[13,14]}$

When fetuses with chromosomal abnormalities were excluded from the study, PAPP-A levels in the first trimester were found to be correlated with pregnancy complications. In some studies, higher levels of PAPP-A in first trimester correlated with preeclampsia; however, in many other studies, authors reported lack of any correlation between PAPP-A levels and preeclampsia. ${ }^{[15,16]}$ In other words, this issue has not been determined conclusively.

Another hormone, beta subunit of human chorionic gonadotropin ( $\beta \mathrm{hCG}$ ) has also been routinely used as a component of double test for monito- ring pregnant women. Decreased level of $\beta$ hCG in the first trimester has been found to be correlated with low birth weight and spontaneous abortus. In recurrent miscarriages and unexplained cases of infertility, mutations in $\beta \mathrm{hCG}$ gene transcription have been detected. ${ }^{[15,17,18]}$

Weakened placentation and smaller placenta have been associated with lower $\beta$ hCG levels in first and second trimesters of complicated pregnancies. ${ }^{[19]}$

Between II and I4 gestational weeks, $5 \%$ of fetuses had nuchal translucency (NT) above $95^{\text {th }}$ percentile. Many of these fetuses have normal chromosomal and anatomic structure during antenatal period and at birth; however, they have higher risk of developing major cardiac anomalies, other structural abnormalities, rarely seen genetic syndromes, and other adverse pregnancy outcomes. ${ }^{[20-22]}$

Maternal serum alfa fetoprotein (msAFP) is another hormone, evaluated between 16 and 18 gestational weeks for Down syndrome and neural tube defects. In the detection of IUGR, some studies have emphasized importance of higher msAFP values. In 2008, Gagnon et al. indicated presence of an association between msAFP value and IUGR. ${ }^{[23]}$

In recent years, the attention of researchers has been concentrated on determination of fetal condition and measurement of flow patterns in fetal vessels. Currently, many randomized controlled studies have demonstrated that using these modalities might decrease fetal mortality rates and delivery of preterm IUGR fetuses caused by unnecessary induction of labor. ${ }^{[24]}$

However, loss of end-diastolic blood flow or presence of retrograde blood flow in umbilical artery heralds adverse fetal outcomes. In cases with normal umbilical artery blood flow, very rarely are significant fetal morbidities detected, and most of the time, constitutional growth retardation is reported. ${ }^{[25]}$ More importantly, in fetuses where abnormal Doppler US findings are detected in venous circulation (ductus venosus and umbilical vein), an imminent life-threatening event can occur. ${ }^{[26]}$

Although fetal growth is thought to be very closely related to events occurring during second trimester, recent studies have demonstrated that placental development in first trimester determines the developmental and growth pattern of the fetus. ${ }^{[27,28]}$ Naturally, potential use of double test 
(PAPP-A, and $\beta \mathrm{hCG}$ ) for early detection of IUGR, which effects fetal prognosis, would be an effective diagnostic modality without incurring additional financial burden.

In 2 large-scale studies performed recently, lower PAPP-A levels were associated with increased risk of being an infant with SGA. ${ }^{[29,30]}$

Despite detection of closer association between maternal PAPP-A level and birth weight within first trimester in these studies, measurements of crown-rump length (CRL) in first trimester was not investigated.

Furthermore, the authors of these studies did not discuss whether birth weight is correlated with measurements of PAPP-A and CRL, independently or in combination.

The purpose of the present study was both to investigate correlation between infant birth weight and measurement of crown-rump length (CRL), neck translucency (NT), PAPP-A, $\beta$ HCG, msAFP, and uterine artery notch as detected on Doppler US, and to evaluate their predictive value in the detection of SGA.

\section{PATIENTS AND METHODS}

This investigation was designed as a prospective observational study. Pregnant women in their first trimester who came to the obstetric polyclinic of the hospital between June 2010 and June 20II for routine visits were included in the study. Patients with multiple pregnancies, systemic disease, or anomalous fetus detected during follow-up were excluded. Approval of the Kartal Dr. Lütfi Kırdar Training and Research Hospital ethics committee was obtained. All patients were informed about the study and provided signed consent forms indicating that they had been given information concerning the study.

A total of 103 patients completed the study. At first admission, height and body weight of all patients were measured, and body mass index (BMI) was calculated. Their obstetric and medical anamneses were recorded. They were asked about smoking status. Their gestational age was confirmed with US examination. Necessary biochemical examinations were requested, and those with abnormal test results were excluded from the study. For first trimester screening tests, follow-up vi- sits were optimally arranged for $1 \mathrm{I}-13+6$ weeks. Measurements of CRL and NT were performed. Blood samples were collected for measurement of maternal serum free $\beta \mathrm{HCG}$ and PAPP-A values. Their results were recorded in MoM values appropriate for number of gestational weeks. Between $16^{\text {th }}$ and $18^{\text {th }}$ week, blood samples were drawn to measure maternal serum AFP level and MoM values were recorded. Biochemical markers were measured immediately after blood samples were obtained using Kryptor analyzer (Brahms Diagnostica $\mathrm{GmbH}$, Berlin, Germany). Apart from routine follow-up process, biometric measurements and screening tests for anomalies (if any) were performed. Umbilical artery pulsatility index (PI), resistance index (RI), and systolic/diastolic (S/D) parameters, as well as presence of uterine artery notch on Doppler US were analyzed. Hemoglobin values were determined. Birth weight, gestational weeks, presence of gestational diabetes, preeclamptic, and premature deliveries were recorded. Newborns with birth weight below $10^{\text {th }}$ percentile constituted the SGA group, and remainder were designated the control group. Based on these criteria, 83 women delivered infants with normal birth weight. Patient data of both groups were compared. For statistical analysis, SPSS software (Statistical Package for Social Sciences version 16.0; SPSS Inc., Chicago, IL, USA) was used. Mean values were compared using independent-t test, and rates were compared using chi-square test. Pearson correlation test was used for the correlation of data with SGA, and $p<0.05$ was evaluated as the level of statistical significance.

\section{RESULTS}

Twenty patients with SGA and 83 with appropriate gestational age (AGA) or normal birth weight babies completed the study. Patient characteristics are shown in Table I. Average body weight of mothers with SGA babies was statistically significantly different from mothers who delivered babies with gestational age-adjusted normal body weight $(p=0.03)$. The same result was also demonstrated with Pearson correlation test $(p=0.03 ; r=0.283)$. Other patient characteristics were the same in both groups.

Mean values for screening biomarkers, CRL, NT measurements, and hemoglobin values in the first trimester are shown in Table 2. Mean CRL measu- 
Table 1. Patient characteristics

\begin{tabular}{lccc}
\hline & $\begin{array}{c}\text { SGA } \\
\text { (Small for gestational age) }\end{array}$ & $\begin{array}{c}\text { AGA } \\
\text { (Appropiate gestational age) }\end{array}$ & p \\
\hline Age (years) & $29.60 \pm 5.83$ & $29.19 \pm 4.95$ & $\mathrm{NS}^{*}$ \\
Weight $(\mathrm{kg})$ & $61.4 \pm 14.01$ & $68.56 \pm 13.38$ & 0.03 \\
Height $(\mathrm{cm})$ & $159.70 \pm 6.30$ & $161.57 \pm 6.44$ & $\mathrm{NS}^{*}$ \\
Gravida (median value) & 2 & 3 & $\mathrm{Ns}^{*}$ \\
Body mass index $\left(\mathrm{kg} / \mathrm{m}^{2}\right)$ & $24.13 \pm 4.27$ & $26.23 \pm 3.12$ & 0.03 \\
\hline
\end{tabular}

SGA: Small for gestational age; AGA: Appropriate for gestational age. *Not significant (NS).

Table 2. Screening results for the first trimester

\begin{tabular}{|c|c|c|c|}
\hline & SGA & AGA & $p$ \\
\hline & Mean \pm Standard deviation & Mean \pm Standard deviation & \\
\hline Gestational week & $12.24 \pm 0.84$ & $12.24 \pm 0.57$ & $\mathrm{NS}^{*}$ \\
\hline $\mathrm{CRL}(\mathrm{mm})$ & $59.35 \pm 11.28$ & $60.78 \pm 6.67$ & $\mathrm{NS}^{*}$ \\
\hline $\mathrm{NT}(\mathrm{mm})$ & $1.15 \pm 0.41$ & $1.01 \pm 0.27$ & $\mathrm{NS}^{*}$ \\
\hline PAPP-A (MoM) & $1.42 \pm 1.07$ & $1.35 \pm 1.59$ & $\mathrm{NS}^{*}$ \\
\hline$\beta h C G(M o M)$ & $1.35 \pm 0.56$ & $1.22 \pm 1.51$ & $\mathrm{NS}^{*}$ \\
\hline Hemoglobin (g/dl) & $12.28 \pm 1.08$ & $11.69 \pm 1.16$ & $\mathrm{NS}^{*}$ \\
\hline
\end{tabular}

rements in first trimester did not differ significantly between infants with SGA and age-adjusted normal birth weight babies. Mean PAPP-A, $\beta$ hCG, and hemoglobin values were comparable between both groups. No difference was observed between mean NT measurements.

Mean values of biometric parameters measured during second trimester, including biparietal diameter (BPD), femur length ( $F L)$, head circumference ( $\mathrm{HC})$, mean MoM of alpha-fetoprotein (AFP), presence of uterine artery notch as detected on Doppler US, and mean hemoglobin values are shown in Table 3.

Second trimester screening tests were performed on participants within approximately the same gestational week. Biophysical measurements of the fetuses did not differ. Uterine artery notch was more frequently detected in pregnant women who delivered SGA infants, though a statistically significant difference was not observed between groups. Mean AFM MoM measured during second trimester was significantly higher in pregnancies with SGA fetuses $(p=0.009)$. The same findings were also revealed in Pearson correlation test $(p=0.028 ; r=-0.327)$.

As seen in Table 4, mean gestational week at birth in each SGA group was significantly less than that of the control group $(p=0.018)$. Prematurity was significantly more frequent in the SGA group relative to the control group $(p<0.01)$. Mean birth weights of the SGA and AGA infants were $2216 \pm 58 \mathrm{I}$ gr and $3391 \pm 386$ gr, respectively; however, no intergroup difference was found in hemoglobin values or frequency of gestational diabetes. On the other hand, preeclampsia was more frequently detected in the SGA group $(p=0.027)$.

Male to female ratio of both groups was nearly equivalent. Mean birth weight, CRL, and mean values of serum markers did not differ between male and female infants. Only mean NT value of male fetuses $(0.96 \pm 0.23)$ was significantly higher than that of the female fetuses $(p=0.005)$. Biophysical measurements of the fetuses during second trimester were comparable between genders. 
Table 3. Biometric measurements, umbilical, and uterine artery Doppler US findings, and hemoglobin values of the fetuses in their second trimesters

\begin{tabular}{lccc}
\hline & SGA & AGA & p \\
\hline Gestational week & $22.77 \pm 1.71$ & $22.05 \pm 1.66$ & $\mathrm{NS}^{*}$ \\
BPD & $22.21 \pm 1.62$ & $22.24 \pm 1.65$ & $\mathrm{NS}^{*}$ \\
HC & $21.76 \pm 1.68$ & $22.03 \pm 1.65$ & $\mathrm{NS}^{*}$ \\
FL & $21.85 \pm 1.77$ & $21.98 \pm 1.66$ & $\mathrm{NS}^{*}$ \\
AC & $22.19 \pm 1.48$ & $22.12 \pm 1.64$ & $\mathrm{NS}^{*}$ \\
Uterine artery diastolic notch & $4(28.6 \%)$ & $6(9.7 \%)$ & $\mathrm{NS}^{*}$ \\
AFP (MoM) & $1.58 \pm 0.45$ & $1.07 \pm 0.75$ & 0.009 \\
Hemoglobin (g/dl) & $12.09 \pm 1.50$ & $11.41 \pm 0.94$ & $\mathrm{NS}^{*}$ \\
\hline
\end{tabular}

SGA: Small for gestational age; AGA: Appropriate for gestational age; BPD: Biparietal diameter; HC: Head circumference; FL: Femur length; AC: Abdominal circumference; AFP: Alpha fetoprotein. ${ }^{*}$ Not significant (NS).

Table 4. Mean gestational weeks, birth weights, hemoglobin values, rates of gestational diabetes, premature births, and preeclampsia, and gender distribution in both groups

\begin{tabular}{lccc}
\hline & SGA & AGA & p \\
\hline Gestational week & $36.89 \pm 2.90$ & $38.62 \pm 1.68$ & 0.018 \\
Birth weight (gr) & $2216 \pm 581$ & $3391 \pm 386$ & $<0.0001$ \\
Gender of the baby & $12 \mathrm{~F}, 8 \mathrm{M}$ & $53 \mathrm{~F}, 30 \mathrm{M}$ & $\mathrm{NS}^{*}$ \\
Premature birth & $6(30 \%)$ & $6(6.7 \%)$ & $<0.001$ \\
Preeclampsia & $8(40 \%)$ & $13(15.7 \%)$ & 0.027 \\
Gestational diabetes & $1(5 \%)$ & $7(8.4 \%)$ & $\mathrm{NS}^{*}$ \\
Hemoglobin value at birth $(\mathrm{g} / \mathrm{dl})$ & $11.35 \pm 1.33$ & $10.93 \pm 1.21$ & $\mathrm{NS}^{*}$ \\
\hline
\end{tabular}

F: Female; M: Male; SGA: Small for gestational age; AGA: Appropriate for gestational age. *Not significant (NS).

\section{DISCUSSION}

In 1998, Smith et al. investigated factors affecting low birth weight, comparing smokers and nonsmokers during the first trimester, and observed lower PAPP-A values in smokers. ${ }^{[3]}$ This outcome suggested that PAPP-A secreted from trophoblasts might be related to premature development of fetus and placentation. However, in studies performed separately by Dugoff et al. and Krantz et al., a relatively prominent correlation between low birth weight and PAPP-A levels was not seen. The same results were observed by Spencer et al. in 2008. ${ }^{[30,32,33]}$ Next, they tried to increase predictive impact for early detection of IUGR and added first trimester CRL to PAPP-A. In the study by Leung et al. realized in 2008, the authors revealed that decreases in both first trimester CRL and PAPP-A were independent risk factors for lower birth we- ight. ${ }^{[34]}$ In the present study, mean PAPP-A values for SGA babies and AGA babies were 1.42 \pm 1.077 and $1.35 \pm 1.59$, respectively, without a significant difference between them.

Like PAPP-A, the biomarker $\beta$ hCG has been also investigated for the prediction of IUGR. Contrary to PAPP-A, $\beta$ hCG does not directly affect fetal development. However, its levels may drop related to placental insufficiency. In many studies, the correlation between lower $\beta$ hCG values and its predictive value for SGA has been considered a debatable issue. ${ }^{[29]}$ Variations in the etiology of SGA may account for differences among study outcomes. In the present study, a statistically significant difference as far as PAPP-A and $\beta$ hCG values was not detected in the SGA group when compared with the normal group.

In a study by Pihl et al. conducted in 2008 , the authors investigated predictive values of NT, PAPP-A, 
and $\beta$ hCG in the prediction of low birth weight. In their study, correlations were found between lower PAPP-A and $\beta$ hCG values and low birth weight. However, NT value did not demonstrate such a strong correlation. ${ }^{[35]}$ The results of this study comply with those of Tul et al. (2003), Dugoff et al. (2004), and Krantz et al. (2004). ${ }^{[30,32,36]}$ In the current study, NT values were within normal limits in both groups without any statistically significant difference between groups (Table 2).

The importance of higher AFP in the prediction of IUGR has been stressed in many studies. In 2008, Gagnon et al. demonstrated a correlation between AFP value and IUGR. ${ }^{[23]}$ Many other studies cited in the literature have supported the results of this study. Morris et al. revealed that AFP levels above 2 MoM, apart from anomalies, could detect low birth weight in $27 \%$ of cases. ${ }^{[37]}$ Also in the present study, a significantly higher mean AFP level was detected in the group with SGA babies.

In the present study, first trimester $1 \mathrm{I}-13+6$ week $\mathrm{CRL}$ and fetal biophysical measurements at gestational 20 to 24 weeks for SGA were not different when compared with estimates for normal term pregnant women. However, in a study performed by Law et al., the authors detected significant correlations between birth weight of fetuses at $18^{\text {th }}$ to $22^{\text {nd }}$ week gestational age and biophysical profiles such as BPD, HC, AC, and placenta volume. In the same study, uterine artery $\mathrm{Pl}$ in first and second trimesters was found to be correlated with IUGR. According to their outcomes, uterine artery $\mathrm{PI}$ is an independent indicator for IUGR. ${ }^{[38]}$ The present study results are in accordance with other studies that demonstrated correlations between uterine artery blood flow and IUGR. ${ }^{[39-41]}$ Uterine artery PI reflects placental resistance against uterine blood flow, and thus perfectly evaluates placental function. In the current study also, when presence of uterine artery notch, which is an indicator of this resistance, was examined, a significantly greater number of uterine notches were seen in IUGR babies born between $20^{\text {th }}$ and $24^{\text {th }}$ gestational week. This result confirms the outcomes of other studies.

Rates of gestational diabetes were similar in both groups, while frequency of preeclampsia was expectedly, and significantly, higher among SGA babies. In the present study, IUGR was detected in $20 \%$ of fetuses. This condition can be explained by the fact that our hospital is a reference hospital with high-risk patients at our clinics.

When premature birth rates are reviewed, it can be seen that $30 \%$ of the SGA babies and only $6.7 \%$ of the control group were premature. These outcomes complied with etiology and treatment of IUGR.

In conclusion, in this study it has been demonstrated that first trimester serum markers in the group with SGA do not differ significantly from those of the normal group. On the other hand, we have shown that AFP value measured between 16 and 18 gestational weeks, and uterine artery Doppler values detected between 20 and 24 gestational weeks can be effective in predicting IUGR. Although studies cited in the literature have considered varying serum markers, they haven't demonstrated a significant and effective first trimester US or serum marker that will detect IUGR at an early stage. The present study supports these findings.

Conflict of interest

None declared.

\section{REFERENCES}

1. Unterscheider J, O’Donoghue K, Daly S, Geary MP, Kennelly MM, McAuliffe FM, et al. Fetal growth restriction and the risk of perinatal mortality-case studies from the multicentre PORTO study. BMC Pregnancy Childbirth 2014; $14: 63$.

2. Lindqvist PG, Molin J. Does antenatal identification of small-for-gestational age fetuses significantly improve their outcome? Ultrasound Obstet Gynecol 2005;25:258-64.

3. M Kady S, Gardosi J. Perinatal mortality and fetal growth restriction. Best Pract Res Clin Obstet Gynaecol 2004;18:397-410.

4. Bernstein IM, Horbar JD, Badger GJ, Ohlsson A, Golan A. Morbidity and mortality among very-low-birthweight neonates with intrauterine growth restriction. The Vermont Oxford Network. Am J Obstet Gynecol 2000;182(1 Pt 1):198-206.

5. Simchen MJ, Beiner ME, Strauss-Liviathan N, Dulitzky M, Kuint J, Mashiach S, et al. Neonatal outcome in growth-restricted versus appropriately grown preterm infants. Am J Perinatol 2000;17:187-92.

6. Paz I, Laor A, Gale R, Harlap S, Stevenson DK, Seidman DS. Term infants with fetal growth restriction are not at increased risk for low intelligence scores at age 17 years. J Pediatr 2001;138:87-91.

7. Blair E, Stanley F. Intrauterine growth and spastic cerebral palsy. I. Association with birth weight for gestational age. Am J Obstet Gynecol 1990;162:229-37.

8. Lubchenco Lo, Hansman C, Dressler M, Boyd E. Intrauterine Growth As Estimated From Liveborn 
Birth-Weight Data At 24 To 42 Weeks Of Gestation. Pediatrics 1963;32:793-800.

9. Maanning FA. Intrauterin growth retardation. In: Manning FA, editor. Fetal medicine: Principles and practice. Nor-walk, CT: Appleton and Lange; 1995.

10. Williams RL, Creasy RK, Cunningham GC, Hawes WE, Norris FD, Tashiro M. Fetal growth and perinatal viability in California. Obstet Gynecol 1982;59:624-32.

11. Dayal AK, Manning FA, Berck DJ, Mussalli GM, Avila C, Harman CR, et al. Fetal death after normal biophysical profile score: An eighteen-year experience. Am J Obstet Gynecol 1999;181(5 Pt 1):1231,6.

12. Oxvig C, Sand O, Kristensen T, Gleich GJ, Sottrup-Jensen L. Circulating human pregnancy-associated plasma protein-A is disulfide-bridged to the proform of eosinophil major basic protein. J Biol Chem 1993;268:122436.

13. Lin TM, Galbert SP, Kiefer D, Spellacy WN, Gall S. Characterization of four human pregnancy-associated plasma proteins. Am J Obstet Gynecol 1974;118:22336.

14. Brizot ML, Snijders RJ, Bersinger NA, Kuhn P, Nicolaides $\mathrm{KH}$. Maternal serum pregnancy-associated plasma protein $\mathrm{A}$ and fetal nuchal translucency thickness for the prediction of fetal trisomies in early pregnancy. Obstet Gynecol 1994;84:918-22.

15. Yaron Y, Heifetz S, Ochshorn Y, Lehavi O, Orr-Urtreger A. Decreased first trimester PAPP-A is a predictor of adverse pregnancy outcome. Prenat Diagn 2002;22:77882.

16. Gagnon A, Wilson RD, Audibert F, Allen VM, Blight C, Brock JA, et al. Obstetrical complications associated with abnormal maternal serum markers analytes. J Obstet Gynaecol Can 2008;30:918-49.

17. Lawrence JB, Oxvig C, Overgaard MT, Sottrup-Jensen L, Gleich GJ, Hays LG, et al. The insulin-like growth factor (IGF)-dependent IGF binding protein-4 protease secreted by human fibroblasts is pregnancy-associated plasma protein-A. Proc Natl Acad Sci U S A 1999;96:3149-53.

18. Yıldırım N, Kaleli B. Prenatal tanıda biyokimyasal yöntemler. In: Beksaç M, Demir N, Koç A, Yükssel A, editors. Maternal fetal tıp-perinatoloji. 2001. p. 201-21.

19. Tanrıverdi H, Çınar E, Sade H. Birinci trimester fetal anomali tarama testleri. In: Çiçek MN, Akyürek C, Çelik Ç, Haberal A, editors. Kadın hastalıkları ve doğum bilgisi. 2. baskı, Ankara: Güneș kitapevi; 2006. p. 381-98.

20. Pandya PP, Snijders RJ, Johnson SP, De Lourdes Brizot M, Nicolaides KH. Screening for fetal trisomies by maternal age and fetal nuchal translucency thickness at 10 to 14 weeks of gestation. Br J Obstet Gynaecol 1995;102:957-62.

21. Souka AP, Krampl E, Bakalis S, Heath V, Nicolaides $\mathrm{KH}$. Outcome of pregnancy in chromosomally normal fetuses with increased nuchal translucency in the first trimester. Ultrasound Obstet Gynecol 2001;18:9-17.

22. Chitty LS, Pandya PP. Ultrasound screening for fetal abnormalities in the first trimester. Prenat Diagn
1997;17:1269-81.

23. Gagnon A, Wilson RD, Audibert F, Allen VM, Blight C, Brock JA, et al. Obstetrical complications associated with abnormal maternal serum markers analytes. $\mathrm{J} \mathrm{Ob-}$ stet Gynaecol Can 2008;30:918-49.

24. Alfirevic Z, Neilson JP. Doppler ultrasonography in high-risk pregnancies: systematic review with metaanalysis. Am J Obstet Gynecol 1995;172:1379-87.

25. Ott WJ. Intrauterine growth restriction and Doppler ultrasonography. J Ultrasound Med 2000;19:661-7.

26. Hecher K, Campbell S, Doyle P, Harrington K, Nicolaides K. Assessment of fetal compromise by Doppler ultrasound investigation of the fetal circulation. Arterial, intracardiac, and venous blood flow velocity studies. Circulation 1995;91:129-38.

27. Gluckman PD, Liggins GC. Regulation fetal growth. In: Beard RW, Nathanielsz PW, editors. Fetal physiology and medicine. New York: Dekker; p. 1992. p. 511-58.

28. Smith GC. First trimester origins of fetal growth impairment. Semin Perinatol 2004;28:41-50.

29. Smith GC, Stenhouse EJ, Crossley JA, Aitken DA, Cameron AD, Connor JM. Early pregnancy levels of pregnancy-associated plasma protein a and the risk of intrauterine growth restriction, premature birth, preeclampsia, and stillbirth. J Clin Endocrinol Metab 2002;87:1762-7.

30. Krantz D, Goetzl L, Simpson JL, Thom E, Zachary J, Hallahan TW, et al. Association of extreme firsttrimester free human chorionic gonadotropin-beta, pregnancy-associated plasma protein $\mathrm{A}$, and nuchal translucency with intrauterine growth restriction and other adverse pregnancy outcomes. Am J Obstet Gynecol 2004;191:1452-8.

31. Smith GC, Smith MF, McNay MB, Fleming JE. Firsttrimester growth and the risk of low birth weight. $\mathrm{N}$ Engl J Med 1998;339:1817-22.

32. Dugoff L, Hobbins JC, Malone FD, Porter TF, Luthy $\mathrm{D}$, Comstock $\mathrm{CH}$, et al. First-trimester maternal serum PAPP-A and free-beta subunit human chorionic gonadotropin concentrations and nuchal translucency are associated with obstetric complications: a population-based screening study (the FASTER Trial). Am J Obstet Gynecol 2004;191:1446-51.

33. Spencer K, Cowans NJ, Avgidou K, Molina F, Nicolaides KH. First-trimester biochemical markers of aneuploidy and the prediction of small-for-gestational age fetuses. Ultrasound Obstet Gynecol 2008;31:15-9.

34. Leung TY, Sahota DS, Chan LW, Law LW, Fung TY, Leung TN, et al. Prediction of birth weight by fetal crown-rump length and maternal serum levels of pregnancy-associated plasma protein-A in the first trimester. Ultrasound Obstet Gynecol 2008;31:10-4.

35. Pihl K, Sørensen TL, Nørgaard-Pedersen B, Larsen SO, Nguyen TH, Krebs L, et al. First-trimester combined screening for Down syndrome: prediction of low birth weight, small for gestational age and pre-term delivery in a cohort of non-selected women. Prenat Diagn $2008 ; 28: 247-53$. 
36. Tul N, Pusenjak S, Osredkar J, Spencer K, Novak-Antolic $Z$. Predicting complications of pregnancy with first-trimester maternal serum free-betahCG, PAPP-A and inhibin-A. Prenat Diagn 2003;23:990-6.

37. Morris RK, Cnossen JS, Langejans M, Robson SC, Kleijnen J, Ter Riet G, et al. Serum screening with Down's syndrome markers to predict pre-eclampsia and small for gestational age: systematic review and meta-analysis. BMC Pregnancy Childbirth 2008;8:33.

38. Law LW, Leung TY, Sahota DS, Chan LW, Fung TY, Lau TK. Which ultrasound or biochemical markers are independent predictors of small-for-gestational age? Ultrasound Obstet Gynecol 2009;34:283-7.
39. Pilalis A, Souka AP, Antsaklis P, Daskalakis G, Papantoniou N, Mesogitis S, et al. Screening for pre-eclampsia and fetal growth restriction by uterine artery Doppler and PAPP-A at 11-14 weeks' gestation. Ultrasound Obstet Gynecol 2007;29:135-40.

40. Leung TY, Sahota DS, Chan LW, Law LW, Fung TY, Leung TN, et al. Prediction of birth weight by fetal crownrump length and maternal serum levels of pregnancy-associated plasma protein-A in the first trimester. Ultrasound Obstet Gynecol 2008;31:10-4.

41. Niknafs P, Sibbald J. Accuracy of single ultrasound parameters in detection of fetal growth restriction. Am J Perinatol 2001;18:325-34.

\section{Birinci ve İkinci Trimester Biyokimyasal Belirteçlerin ve Ultrason İncelemelerin Bebeğin Doğum Kilosu Üzerine Etkilerinin Araştıııması}

Amaç: Gebelerde baş-popo mesafesi (CRL), ense kalınlığı (NT), gebelik ilişkili plazma protein A (PAPP-A), beta human koryonik gonadotropin (beta hCG), alfa fetoprotein (msAFP) ve uterin arter Doppler ölçümlerinin bebeğin doğum kilosu ile ilişkisinin araştırılması ve intrauterin gelişme geriliğini (IUGG) tahmin edebilme derecesini değerlendirmektir.

Gereç ve Yöntem: Haziran 20I0-Haziran 201 I tarihleri arasında hastanemiz gebe polikliniğine rutin kontrol için gelen ilk trimesterdeki 103 hasta çalışmaya alındı. Doğum ağılığı I0. persentilin altında olanlar IUGG olan grup, diğerleri ise kontrol grubu olarak ikiye ayrıldı. Seksen üç gebelik normal doğum ağılıklı bebek, 20 gebelik düşük doğum ağırlıklı (SGA) bebek doğumu ile sonlandı.

Bulgular: Düşük doğum ağılıklı doğan bebeklerin annelerinin ortalama vücut kitle indeksleri (VKi), kontrol grubuna göre anlamlı olarak düşük bulundu ( $p=0.03)$. İlk trimesterdeki ortalama CRL ölçümlerinde SGA'lı bebeklerde normal kilolu bebeklere göre anlamlı bir farklılık saptanmadı. Anne serumlarındaki ortalama PAPP-A ve $\beta$ hCG ortalama değerleri ve hemoglobin değerleri de her iki grupta aynı bulundu. Fetusların biyofizik ölçümleri arasında fark gözlenmedi. Uterin arterde çentik daha yüksek oranda SGA'lı gebeliklerde olmasına rağmen, istatistiksel olarak iki grup arasında fark saptanmadı. İkinci trimesterde baktı̆̆ımız ortalama AFP MoM (ortalamanın katları) SGA'lı gebeliklerde anlamlı olarak yüksek bulundu $(p=0.009)$. Aynı bulgular Pearson korelasyon testinde de gösterildi $(p=0.028, r=-0.327)$.

Sonuç: Illk trimester serum belirteçlerinin IUGG olan grupta normal gruba göre farklı olmadığı; buna karşılık 20-24. hafta uterin arter Doppler çentik varlığı değerlerinin IUGG'yi tahmin etmede etkili olabileceğini gösterildi. Ayrıca msAFP MoM değeri yüksekliğinin SGA bebeklerle ilişkili olduğunu belirledik.

Anahtar Sözcükler: Doppler renkli ultrasonografi; HCG-beta; nukal kalınlık ölçümü; PAPP-A; intrauterin gelişme geriliği. 